\title{
Effect of precursor concentration on the characteristics of nanoscale zerovalent iron and its reactivity of nitrate
}

\author{
Ya Hsuan Liou ${ }^{a}$, Shang-Lien Lo ${ }^{a, *}$, Wen Hui Kuan ${ }^{b}$, Chin-Jung Lin ${ }^{a}$, Shih Chi Weng ${ }^{a}$ \\ ${ }^{a}$ Research Center for Environmental Pollution Prevention and Control Technology, Graduate Institute of Environmental Engineering, \\ National Taiwan University, Taipei 106, Taiwan \\ ${ }^{\mathrm{b}}$ Department of Environmental and Safety Engineering, Ming-Chi Institute of Technology, Taishan, Taipei hsien 243, Taiwan
}

\section{A R T I C L E I N F O}

Article history:

Received 30 July 2005

Received in revised form

11 April 2006

Accepted 26 April 2006

Keywords:

Precursor concentrations

Nanoscale $\mathrm{Fe}^{\mathrm{O}}$

Nitrate

\begin{abstract}
A B S T R A C T
Differing precursor concentrations, $1.0,0.1$, and $0.01 \mathrm{M} \mathrm{FeCl} \cdot 6 \mathrm{H}_{2} \mathrm{O}$, were performed to produce nanoscale $\mathrm{Fe}^{0}$ and the results were discussed in terms of the specific surface area, particle size and electrochemical properties. The results indicated that the nanoscale $\mathrm{Fe}^{0}$ prepared by $0.01 \mathrm{M} \mathrm{FeCl}_{3}$ had absolutely reduced in size $(9-10 \mathrm{~nm})$ and possessed the greatest specific surface area $\left(56.67 \mathrm{~m}^{2} \mathrm{~g}^{-1}\right)$. These synthesized nanoscale $\mathrm{Fe}^{0}$ particles were attempted to enhance the removal of $40 \mathrm{mg}^{-\mathrm{NL}^{-1}}$ unbuffered nitrate solution. The firstorder degradation rate constants $\left(k_{\text {obs}}\right)$ increased significantly (5.5-8.6 times) with nanoscale $\mathrm{Fe}^{0}$ prepared by $0.01 \mathrm{M}$ precursor solution $\left(\mathrm{Fe}_{0.01 \mathrm{M}}^{0}\right)$. When normalized to iron surface area concentration, the specific rate constant $\left(k_{\mathrm{SA}}\right)$ was increased by a factor of approximately 1.7-2.4 using $\mathrm{Fe}_{0.01 \mathrm{M}}^{0}\left(6.84 \times 10^{-4} \mathrm{~L} \mathrm{~min}^{-1} \mathrm{~m}^{-2}\right.$ for $\mathrm{Fe}_{0.01 \mathrm{M}}^{0}, 4.04 \times$ $10^{-4} \mathrm{~L} \mathrm{~min}^{-1} \mathrm{~m}^{-2}$ for $\mathrm{Fe}_{0.1 \mathrm{M}}^{0}$ and $2.80 \times 10^{-4} \mathrm{~L} \mathrm{~min}^{-1} \mathrm{~m}^{-2}$ for $\mathrm{Fe}_{1 \mathrm{M}}^{0}$ ). The rise of reactivity of the reactive site on the $\mathrm{Fe}_{0.01 \mathrm{M}}^{0}$ surface was indicated by the specific rate constant $\left(k_{\mathrm{SA}}\right)$ calculation and the $i_{0}$ value of the electrochemical test.
\end{abstract}

(c) 2006 Elsevier Ltd. All rights reserved.

\section{Introduction}

Global contamination of groundwater with nitrate has spurred an intense effort to find efficient and cost effective treatment methods. Chemical reduction processes have become a new focus in recent studies. Zerovalent iron $\left(\mathrm{Fe}^{\mathrm{O}}\right)$, the most commonly used material, is a conventional reductant to remove nitrate in water, and its application has been reported in several publications in recent years (Siantar et al., 1996; Cheng et al., 1997a, b; Huang et al., 1998; Zhang et al., 1998; Kielemoes et al., 2000; Alowitz and Scherer, 2001; Schlicker et al., 2003; Westerhoff and James, 2003; Choe et al., 2004; Su and Puls, 2004). Unlike halogenated hydrocarbon reduction, nitrate reduction reaction by $\mathrm{Fe}^{0}$ is relatively sensitive to the solution $\mathrm{pH}$; and nitrate is well known as an oxidizing inhibitor to iron corrosion due to the formation of an overlying oxide layer. Therefore, the nitrate reduction from unbuffered water at initial neutral $\mathrm{pH}$ by $\mathrm{Fe}^{0}$ has relatively rarely been reported. The use of nanoscale $\mathrm{Fe}^{0}$ is currently getting the most attention. Choe et al. (2000) indicated that reducing the size of reductants to nanoscale-dimension would obtain some advantages in $\mathrm{Fe}^{\mathrm{O}} /$ nitrate unbuffered system, including: (1) an increase in reductive degradation reaction rate, (2) a decrease of the reductant dosage, (3) control over the risk of toxic intermediates release and (4) a nontoxic end product, nitrogen gas, is found (Choe et al., 2000).

Previously, it was usually believed that the reduction of particle size would be one of the important parameters to the reduction of nitrate (Wang and Zhang, 1997; Alowitz and Scherer, 2001). Recently, nanoscale $\mathrm{Fe}^{\mathrm{O}}$ particles were prepared by borohydride reduction of an aqueous iron salt in

*Corresponding author. Tel.: +8862 23625373; fax: +886223928821.

E-mail address: sllo@ntu.edu.tw (S.-L. Lo).

0043-1354/\$ - see front matter ( 2006 Elsevier Ltd. All rights reserved.

doi:10.1016/j.watres.2006.04.048 
several studies (Ichinose et al., 1992; Wang and Zhang, 1997; Zhang et al., 1998; Choe et al., 2000; Ponder et al., 2000; Ellott and Zhang, 2001; Schrick et al., 2002; Liao et al., 2003); also, two synthesizing methods were found for nanoscale $\mathrm{Fe}^{\mathrm{O}}$ particle manufacturing. One is by mixing $\mathrm{NaBH}_{4}$ and $\mathrm{FeCl}_{3}$ solutions to form $\mathrm{Fe}^{0}$ particles (Wang and Zhang, 1997; Zhang et al., 1998; Choe et al., 2000; Ellott and Zhang, 2001). The other method is by reducing $\mathrm{FeSO}_{4}$ with $\mathrm{NaBH}_{4}$ (Ponder et al., 2000; Schrick et al., 2002). $\mathrm{Fe}^{0}$ particles formed by the above methods were found to have a BET surface area in the range $18-33.5 \mathrm{~m}^{2} \mathrm{~g}^{-1}$ and the particles are in the size range $1-100 \mathrm{~nm}$ (Wang and Zhang, 1997; Zhang et al., 1998; Ponder et al., 2000; Ellott and Zhang, 2001; Schrick et al., 2002; Liao et al., 2003; Choe et al., 2004). The $\mathrm{Fe}^{0}$ particles preparation by precipitation is usually the result of three processes: (1) particle nucleation, (2) particle growth and (3) secondary changes in the resulting particle suspension by agglomeration (Söhnel and Garside, 1992). However, the process of particle growth by precipitation is complex and no simple way to control the relative rate of nuclear formation and growth has yet been found. Despite the growing number of publications on nitrate reduction by nanoscale $\mathrm{Fe}^{0}$ particles, there is still limited knowledge to evaluate the influence of parameters during the preparation of such nano-particles. The precursor concentration of $\mathrm{Fe}^{0}$ may play an important role on the particle formation and surface characteristics.

In this study, three different concentrations of iron chloride, $1.0,0.1$ and $0.01 \mathrm{M}$, were employed to prepare the nanoscale $\mathrm{Fe}^{0}$ particles for the reduction of nitrate reaction. Attention was also given to the surface characterization through both the investigation of kinetic control and the identification of the electrochemical properties.

\section{Material and methods}

\subsection{Chemicals}

Potassium nitrate and sodium nitrite were purchased from Aldrich (99+\%, Milwaukee, WI). Nessler's Reagent (Fluka) was used for ammonia measurement. The $\mathrm{FeCl}_{3} \cdot 6 \mathrm{H}_{2} \mathrm{O}$ and $\mathrm{NaBH}_{4}$ were obtained from Adlich. All other chemicals used in this work were analytical reagent grade, and solutions were prepared in water purified with a Milli- $\mathrm{Q}^{\mathrm{TM}}$ system

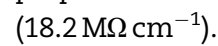

\subsection{Methods for synthesis}

Nanoscale $\mathrm{Fe}^{0}$ particles were prepared by modifying the method of previous literature (Wang and Zhang, 1997; Zhang et al., 1998; Ellott and Zhang, 2001; Choe et al., 2004). Three different concentrations of $\mathrm{FeCl}_{3} \cdot 6 \mathrm{H}_{2} \mathrm{O}, 1.0,0.1$, and $0.01 \mathrm{M}$, were prepared with $30 \%$ technical grade ethanol, $70 \%$ deionized water (v/v). Due to the spillage of hydrogen foaming, $\mathrm{NaBH}_{4}$ solution was carefully added to $\mathrm{FeCl}_{3} \cdot 6 \mathrm{H}_{2} \mathrm{O}$ aqueous solution for the production of synthesized particles. In order to compare the capability of reducing nitrate, the same mass of $\mathrm{Fe}^{0}$ has to be produced from various precursor concentration systems. Therefore, the reaction solution volumes were $0.5,5$, and $50 \mathrm{~mL}$ for the $1.0,0.1$, and $0.01 \mathrm{M}$ $\mathrm{FeCl}_{3}$ systems, respectively.

The reduction of ferric iron $\left(\mathrm{Fe}^{3+}\right)$ leading to $\mathrm{Fe}^{0}$ was the result of redox reaction in which electrons from a reducing agent $\left(\mathrm{NaBH}_{4}\right)$ were transferred to iron according to the following schematic chemical equation:

$\mathrm{Fe}\left(\mathrm{H}_{2} \mathrm{O}\right)_{6}^{3+}+3 \mathrm{BH}_{4}^{-}+3 \mathrm{H}_{2} \mathrm{O} \rightarrow \mathrm{Fe}^{0} \downarrow+3 \mathrm{~B}(\mathrm{OH})_{3}+10.5 \mathrm{H}_{2}$.

The reaction above was carried out at ambient temperature with magnetic stirring. Here, the nanoscale $\mathrm{Fe}^{\mathrm{O}}$ particles prepared by 1.0, 0.1 and $0.01 \mathrm{M} \mathrm{FeCl}_{3} \cdot 6 \mathrm{H}_{2} \mathrm{O}$ are expressed as $\mathrm{Fe}_{1 \mathrm{M}}^{0}, \mathrm{Fe}_{0.1 \mathrm{M}}^{0}$ and $\mathrm{Fe}_{0.01 \mathrm{M}}^{0}$, respectively.

\subsection{Characterization of synthesized particles}

Surface area of the nanoscale $\mathrm{Fe}^{0}$ particles was measured using isothermal nitrogen adsorption method with an ASAP 2010 surface analyzer. Three different concentrations of $\mathrm{FeCl}_{3} \cdot 6 \mathrm{H}_{2} \mathrm{O}(0.01,0.1$ and $0.01 \mathrm{M})$ produced the synthesized particles which were observed with a Hitachi H-7100 transmission electron microscopy (TEM) to characterize the size and size distribution of the metal particles.

The electrochemical analysis experiments were performed using a standard three-electrode cell and the micro-processor-controlled electronic potentiostat (EG\&G, Princeton Applied Research; model 273A) with software Zplot2 and Zview2. The working electrode was a cavity microelectrode (CME), similar to that described by Vivier et al. (1999). The cavity was then filled up with nanoscale $\mathrm{Fe}^{0}$ particles using the electrode as a pestle. A Pt wire was used as the counter electrode and an $\mathrm{Ag} / \mathrm{AgCl}$ electrode was used as the reference. The polarization curves were recorded in the potential range from 0.5 to $0.8 \mathrm{~V}$ at a scan rate of $0.5 \mathrm{mV} \mathrm{s}^{-1}$. An Ar-purged $40 \mathrm{mg}-\mathrm{NL}^{-1}$ nitrate solution was employed to examine the electrochemical corrosion properties of the nanoscale $\mathrm{Fe}^{0}$ particles. All experiments were performed stirring at $200 \mathrm{rpm}$ at $25 \pm 0.1^{\circ} \mathrm{C}$.

\subsection{Batch experiment with $\mathrm{NO}_{3}^{-}$}

Kinetic batch experiments were conducted to investigate reactivity of $\mathrm{Fe}_{1 \mathrm{M}}^{0}, \mathrm{Fe}_{0.1 \mathrm{M}}^{0}$ and $\mathrm{Fe}_{0.01 \mathrm{M}}^{0}$ particles for nitrate reduction reaction. Oxygen has been removed by purging the nitrate solution with argon. Plastic bottles with a $75 \mathrm{~mL}$ capacity were filled with $75-\mathrm{mL}$ samples of $40 \mathrm{mg} \mathrm{NO}-\mathrm{N} / \mathrm{L}$ nitrate aqueous solution and $0.0265 \mathrm{~g}$ of the $\mathrm{Fe}^{0}$ particles. The bottles were capped with Teflon silicone septa and aluminum seals. They were then mixed at $200 \mathrm{rpm}$ using a reciprocal shaker water bath (Yihder, BT-350R) at ambient temperature $\left(25^{\circ} \mathrm{C}\right)$ without $\mathrm{pH}$ control. Then, the samples were filtered using a Milipore filter ( $25 \mathrm{~mm}$ diameter, $0.2 \mu \mathrm{m}$ pore size) at certain time intervals. Filtrates were collected and analyzed immediately.

\subsection{Sample analysis}

Target pollutant, nitrate, and intermediate, nitrite, were measured using an ion chromatograph (Model: Dionex DX$\left.100^{\mathrm{TM}}\right)$ with a column of IonPac AS4A-SC $(4.0 \mathrm{~mm} \times 4.0 \mathrm{~mm}$ I.D.). A mixed solution of $1.7 \mathrm{mM} \mathrm{Na}_{2} \mathrm{CO}_{3}$ and $1.8 \mathrm{mM} \mathrm{NaHCO}_{3}$ 
was used as the mobile phase at a flow rate of $1.0 \mathrm{~mL} \mathrm{~min}^{-1}$. Ammonium was analyzed by indophenol method using a spectrometer (UV SPECTRONIC 20 GENESYS). The pH was measured with a Beckman Model $71 \mathrm{pH}$ meter.

Nitrogen gas was identified by HP5830 GC with a $180 \times 0.63 \mathrm{~cm}$ packed molecular sieve No. 5A column and a thermal conductivity detector. Helium was used as the carrier gas at a flow rate of $30 \mathrm{~mL} \mathrm{~min}^{-1}$. A $1 \mathrm{~mL}$ gaseous sample was withdrawn from the headspace of the reactor. The column temperature was kept at $40^{\circ} \mathrm{C}$. The injection and detector temperature were $100^{\circ} \mathrm{C}$. Peaks were quantified by comparing retention time and peak areas with standard gas (Supelco).

\section{Results and discussions}

\subsection{Characterization of nanoscale zerovalent iron}

Five precursor concentrations, $0.01,0.05,0.1,0.5$, and $1.0 \mathrm{M}$ were used to prepare the nanoscale $\mathrm{Fe}^{0}$. Iron grain sizes were determined by measurement of TEM micrographs. The techniques agreed reasonably to give an average particle size of $9.5,42.5,40.0,45.0$, and $45.0 \mathrm{~nm}$ for nanoscale $\mathrm{Fe}^{0}$ prepared by $0.01,0.05,0.1,0.5$, and $1.0 \mathrm{M}$, respectively (Fig. 1). Nanoscale $\mathrm{Fe}^{0}$ particles prepared by $0.01 \mathrm{M}$ had diameters in the range $9-10 \mathrm{~nm}$. As the precursor concentration was increased, the range of iron particles expanded widely (Fig. 1). This result was immediately apparent in the synthesis that the precursor concentration had a strong effect on the nanoscale $\mathrm{Fe}^{\mathrm{O}}$ particle size in the reaction production.

Three precursor concentrations, $0.01,0.1$, and $1.0 \mathrm{M}$, were chosen for the TEM observation. Figs. 2(a) and (b) present a well-aggregated structure for $\mathrm{Fe}_{1 \mathrm{M}}^{0}$ and $\mathrm{Fe}_{0.1 \mathrm{M}}^{0}$ samples. $\mathrm{TheFe}_{0.01 \mathrm{M}}^{0}$ sample shows isolated particles that are distinctly different from the aggregation. It is small in particle size and, moreover, it is separately formed. The nanoscale $\mathrm{Fe}^{0}$ particles produced by chemical precipitation process are usually the result of three processes: (1) particle nucleation, (2) nuclei growth to primary particles, and (3) secondary changes in the resulting particle suspension by agglomeration (Söhnel and Garside, 1992). The number of nuclei depends on the concentration of precursor solute (Siantar et al., 1996). The same number of nuclei was produced in this experiment because the amounts of ferric ion were equal in different precursor concentrations. Since the nucleation is seldom in the final stage of the $\mathrm{Fe}^{0}$ particle formation, primary particles form thereafter. The precursor concentration decreases as particle growth proceeds, and therefore, large primary particles are produced under dilute precursor solute. As a rule, these primary particles aggregate to form final $\mathrm{Fe}^{\mathrm{O}}$ particles due to their large free energy. However, primary particles and their agglomerates are clearly observed in TEM image (Figs. 2a-c). Von Smoulchowski established that the van der Waals forces become significant when two particles approach within a certain distance. He also defined a sphere action with radius $R$ where $R$ is proximally double the radius of particles $(r)$. Up to separation distance $R$ particles approach without any interaction. On the other hand, when the distance between particles becomes smaller than $R$, the particles adhere irreversibly. In this study, equal amounts of $\mathrm{Fe}^{0}$ per unit were obtained from different volumes and different concentrations of precursor solute. Therefore, a dense solute presents a reduced volume, and compact aggregates occur with strong attraction between particles. Hence Figs. 2(a) and (b) show a compact aggregate structure built up by numerous small primary particles. Due to the weaker bonded aggregate structure, theFe $\mathrm{e}_{0.01 \mathrm{M}}^{0}$ particles are observed as show in Fig. 2(c).

\subsection{Kinetics of nitrate reduction by nanoscale $\mathrm{Fe}^{\mathrm{O}}$}

The reaction rate was evaluated with nitrate unbuffered solution ( $40 \mathrm{mg}^{-\mathrm{NL}^{-1}}$ ) containing $0.0265 \mathrm{~g}$ of $\mathrm{Fe}_{1 \mathrm{M}}^{0}, \mathrm{Fe}_{0.1 \mathrm{M}}^{0}$, and $\mathrm{Fe}_{0.01 \mathrm{M}}^{0}$ particles (Fig. 3). The reduction of nitrate followed pseudo-first-order kinetics with respect to the concentration

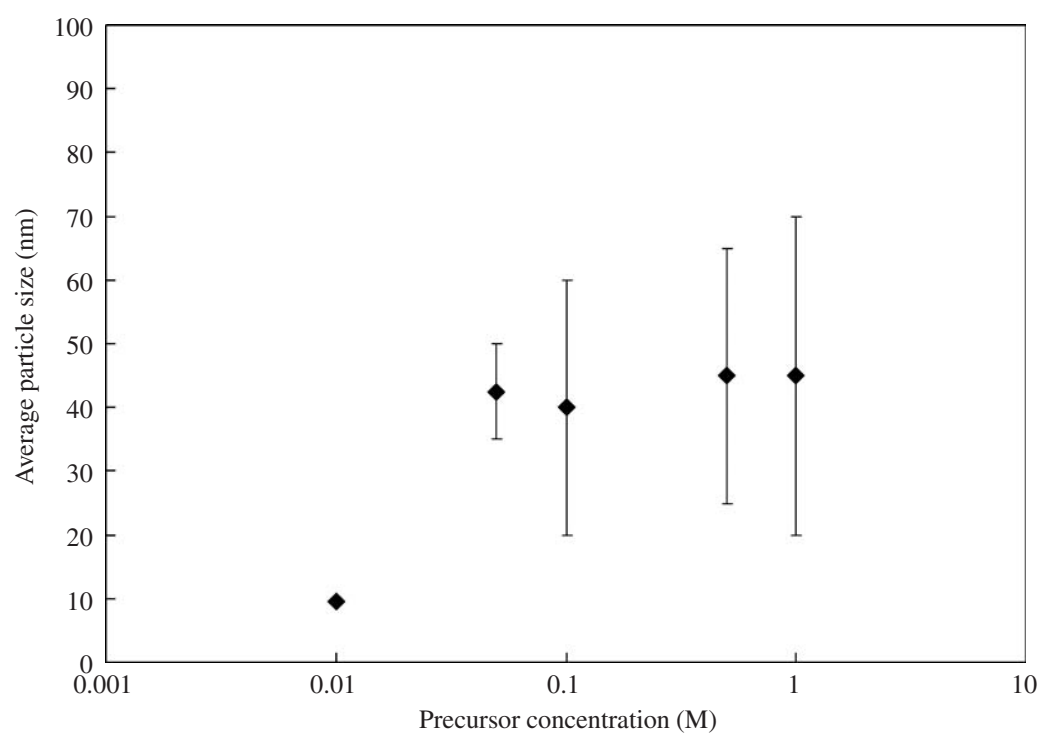

Fig. 1 - Average particle size observed under different precursor concentration production. 

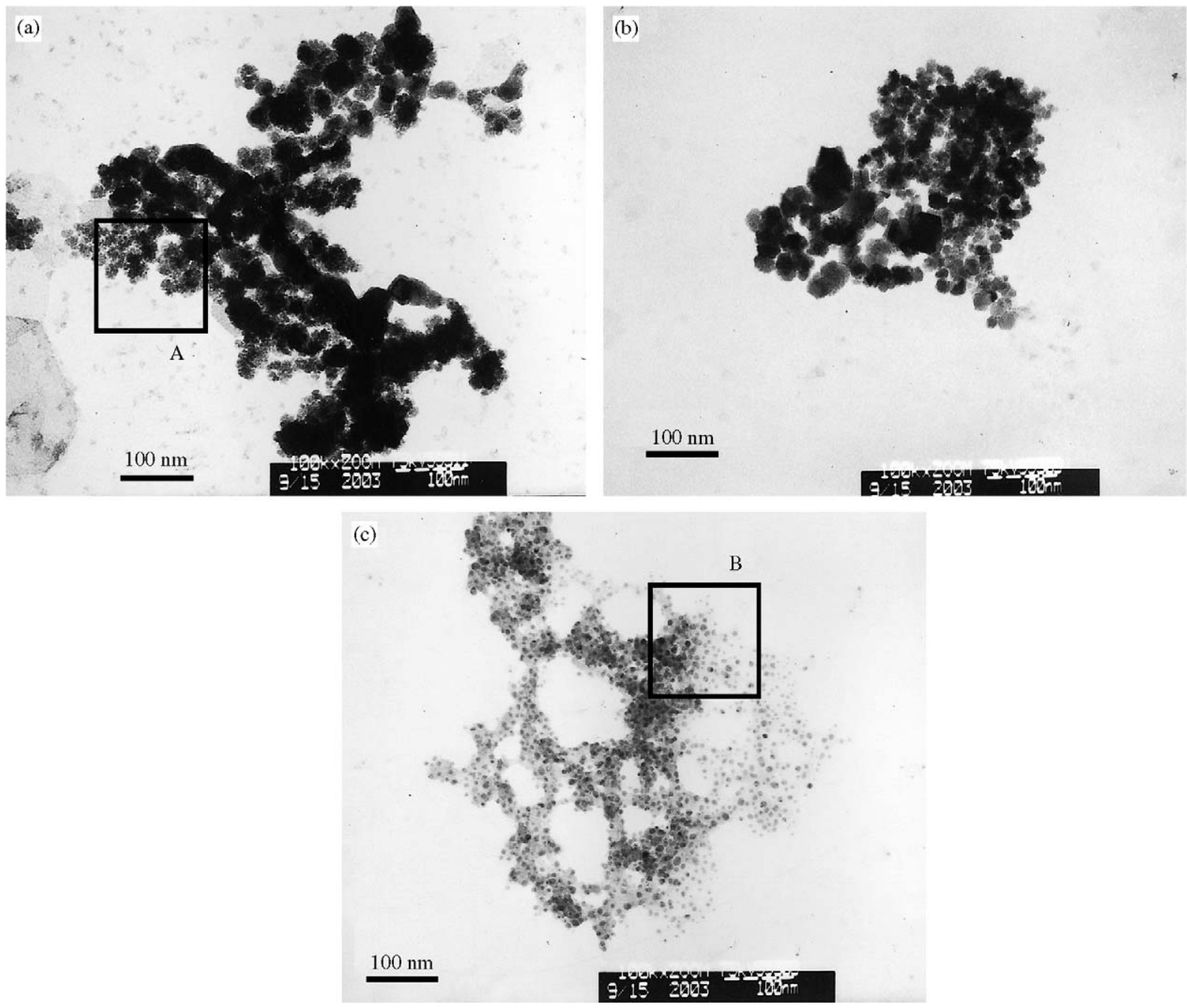

Fig. 2 - Transmission electron microscopy image of nanoscale $\mathrm{Fe}^{0}$ particles produced by: (a) $1.0 \mathrm{M} \mathrm{FeCl}_{3}$, (b) $0.1 \mathrm{M} \mathrm{FeCl} 3$, and (c) $0.01 \mathrm{M} \mathrm{FeCl}_{3}$. A: aggregates of small particles with stronger bond. B: aggregates of small particles with weaker bond.

of nitrate

$r=\frac{-\mathrm{d}\left[\mathrm{NO}_{3}^{-}\right]}{\mathrm{dt}}=k_{\mathrm{obs}}\left[\mathrm{NO}_{3}^{-}\right]$

where $k_{\text {obs }}$ is the observed pseudo-first-order reaction rate constant $\left(\mathrm{min}^{-1}\right)$. The reduction of nitrate using $\mathrm{Fe}_{1 \mathrm{M}}^{0}$ and $\mathrm{Fe}_{0.1 \mathrm{M}}^{0}$ exhibited a stagnation phenomenon at a rate of 0.16 and $0.25 \times 10^{-2} \mathrm{~min}^{-1}$, respectively. Compared with $\mathrm{Fe}_{1 \mathrm{M}}^{0}$ and $\mathrm{Fe}_{0.1 \mathrm{M}}^{0}$, the $k_{\mathrm{obs}}$ value of $\mathrm{Fe}_{0.01 \mathrm{M}}^{0}$ was promoted by a factor of about $5.5-8.5$ to $1.37 \times 10^{-2} \mathrm{~min}^{-1}$. Generally, the nitrate reduction rate is proportional to the amounts of exposed iron surface. Therefore, regarding the iron activity per unit surface area, the $k_{\text {obs }}$ necessarily normalize according to the surface area and the mass concentration of iron particles. The surface area normalized rate constant $\left(k_{\mathrm{SA}}\right)$ can be calculated by

$k_{\mathrm{SA}}=k_{\mathrm{obs}} / \rho_{a}$,

where $\rho_{a}$ is the surface area concentration of iron in $\mathrm{m}^{2} \mathrm{~L}^{-1}$, and here, the $k_{\mathrm{SA}}$ is a parameter of assessment of the overall surface reactivity. The BET surface areas are $16.16 \mathrm{~m}^{2} \mathrm{~g}^{-1}$ for
$\mathrm{Fe}_{1 \mathrm{M}}^{0}, 17.50 \mathrm{~m}^{2} \mathrm{~g}^{-1}$ for $\mathrm{Fe}_{0.1 \mathrm{M}}^{0}$, and $56.67 \mathrm{~m}^{2} \mathrm{~g}^{-1}$ for $\mathrm{Fe}_{0.01 \mathrm{M}}^{0}$ (Table 1). The value of $\rho_{a}$ is $5.71 \mathrm{~m}^{2} \mathrm{~L}^{-1}$ for $\mathrm{Fe}_{1 \mathrm{M}}^{0}, 6.18 \mathrm{~m}^{2} \mathrm{~L}^{-1}$ for $\mathrm{Fe}_{0.1 \mathrm{M}}^{0}$, and $20.02 \mathrm{~m}^{2} \mathrm{~L}^{-1}$ for $\mathrm{Fe}_{0.01 \mathrm{M}}^{0}$ in the batch experiments. Thus the $k_{\mathrm{SA}}$ for $\mathrm{Fe}_{1 \mathrm{M}}^{0}, \mathrm{Fe}_{0.1 \mathrm{M}}^{0}$, and $\mathrm{Fe}_{0.01 \mathrm{M}}^{0}$ were 2.80, 4.04, and $6.84 \times 10^{-4} \mathrm{~min}^{-1} \mathrm{~m}^{-2} \mathrm{~L}$, respectively, as shown in Table 1 . The reactivity of $\mathrm{Fe}_{0.01 \mathrm{M}}^{0}$ was higher relative to both $\mathrm{Fe}_{1 \mathrm{M}}^{0}$ and $\mathrm{Fe}_{0.1 \mathrm{M}}^{0}$ as indicated by a larger $\mathrm{K}_{\mathrm{SA}}$ for $\mathrm{Fe}_{0.01 \mathrm{M}}^{0}$. This fact is due to the decrease of the precursor concentration to $0.01 \mathrm{M}$ with the rise in chemical reactivity in each reactive site on the iron surface (Fig. 3).

Besides being a degradation test of nitrate by $\mathrm{Fe}_{0.01 \mathrm{M}}^{0}$, this research also investigates the reaction stoichiometry and the total nitrogen mass balance (Fig. 4). During experiments, the concentration of nitrate, nitrite, ammonium, nitrogen gas, and $\mathrm{pH}$ value of the solution were monitored. Until now, a pathway for nitrate reduction by $\mathrm{Fe}^{0}$ has not been proposed well. Cheng et al. (1997a,b) and Huang et al. (1998) observed complete reduction of nitrate to ammonia with a pH buffer using a commercially microscale iron powder. In contrast, in nanoscale iron particle condition, Choe et al. (2000) reported $100 \%$ mass recovery as nitrogen gas; however, in some 
Table 1 - The specific surface area, pseudo-first-order rate constant and surface area normalized rates for $\mathrm{Fe}_{0.01 \mathrm{M}}^{0} \mathrm{Fe}_{0.1 \mathrm{M}}^{0}$ and $\mathrm{Fe}_{1 \mathrm{M}}^{0}$

\begin{tabular}{lcc}
\hline & $\mathrm{Fe}_{0.1 \mathrm{M}}^{0}$ & $\mathrm{Fe}_{1 \mathrm{M}}^{0}$ \\
\hline BET specific surface area $\left(\mathrm{m}^{2} \mathrm{~g}^{-1}\right)$ & 16.16 & 17.50 \\
$k_{\mathrm{obs}}\left(10^{-2} \mathrm{~min}^{-1}\right)$ & 0.16 & 0.25 \\
$k_{\mathrm{SA}}\left(10^{-4} \mathrm{~L} \mathrm{~min}^{-1} \mathrm{~m}^{-2}\right)$ & 2.80 & 1.37 \\
\end{tabular}

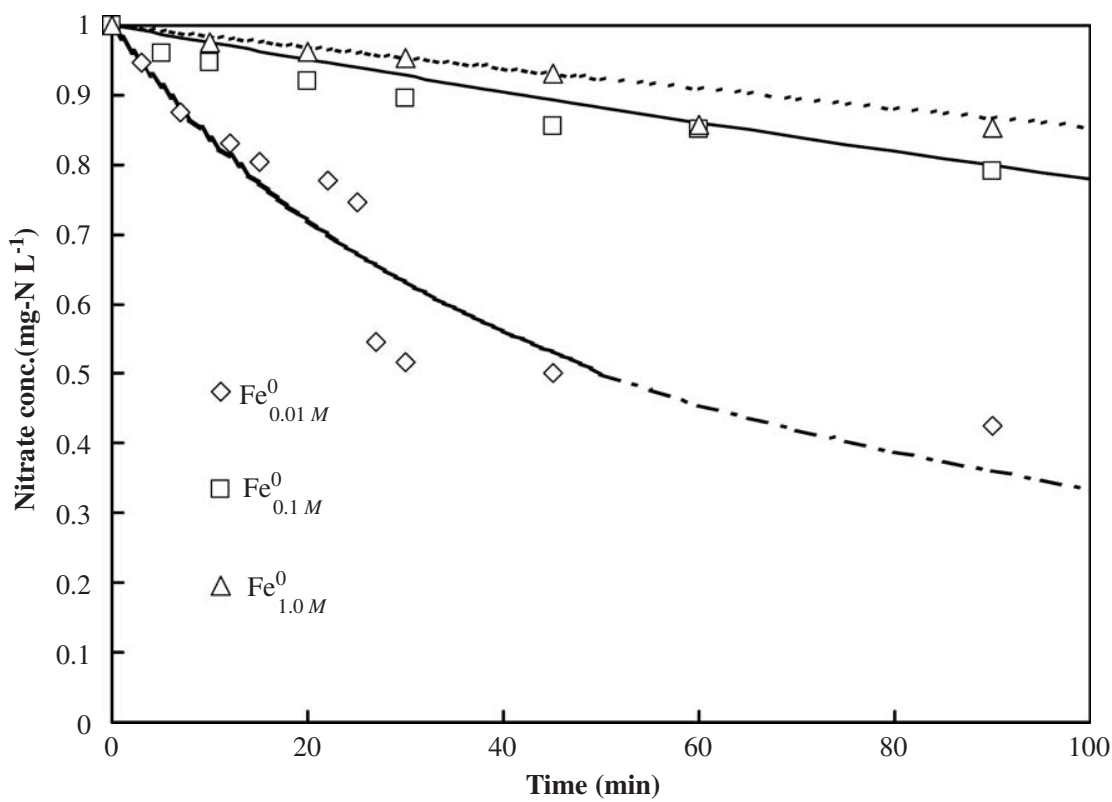

Fig. 3 - A plot of nitrate concentration vs. reaction time. Initial nitrate concentration was $40 \mathrm{mg} \mathrm{NO}{ }_{3}-\mathrm{N} / \mathrm{L} . \mathrm{Fe}^{0}$ content $0.3533 \mathrm{~g} \mathrm{~L}^{-1}$.

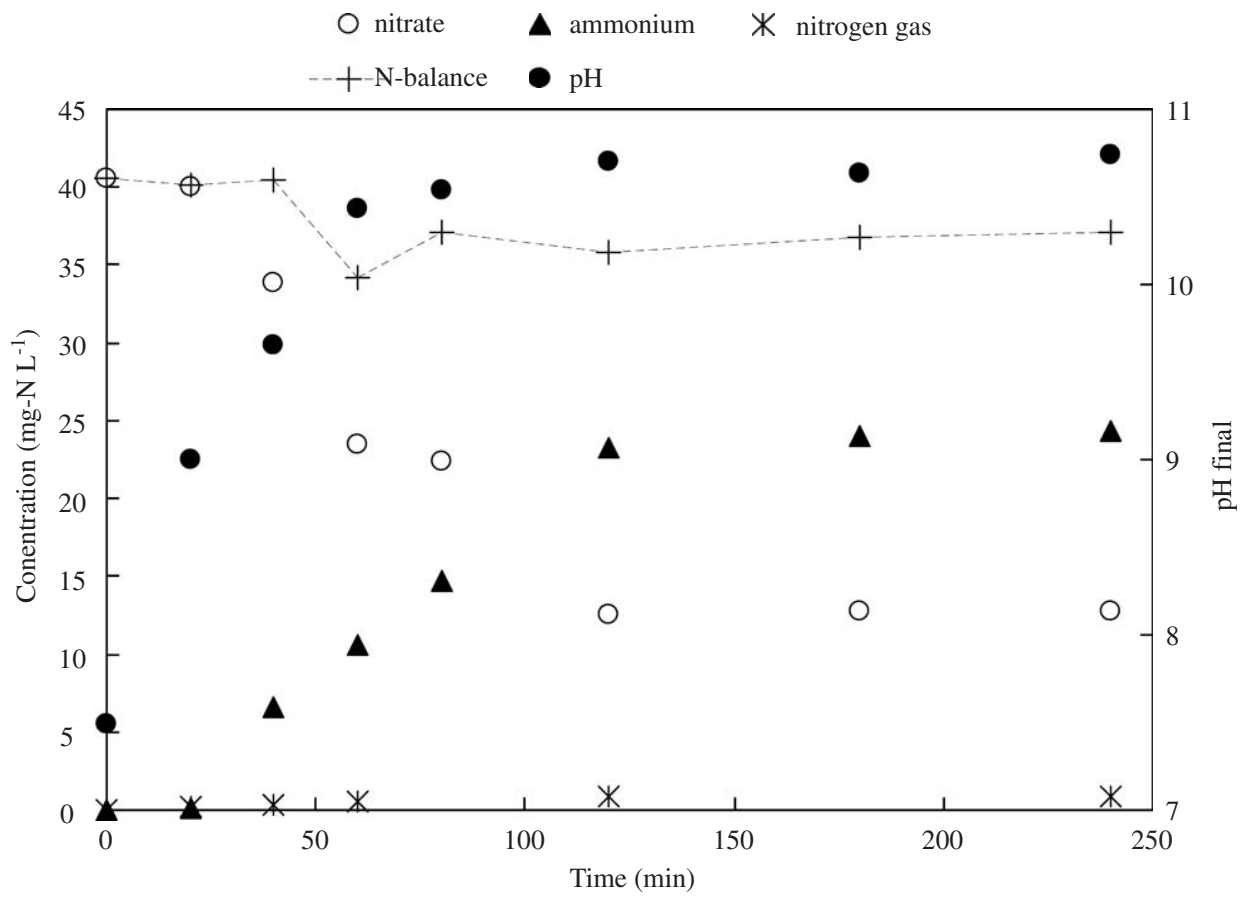

Fig. 4 - Disappearance of nitrate and formation of ammonia with $\mathrm{pH}$ increase. Initial nitrate concentration was $40 \mathrm{mg}$ $\mathrm{NO}_{3}-\mathrm{N} / \mathrm{L} . \mathrm{Fe}^{0} 0.0265 \mathrm{~g} / 75 \mathrm{~mL}$. 
studies, nitrite was found to accumulate as an intermediate product (Westerhoff and James, 2003).

In this study, as nitrate disappeared, ammonium formed accordingly (Fig. 4). Nitrite was not detected while using an ion chromatograph (the detection limit: $0.1 \mathrm{mg}-\mathrm{NL}^{-1}$ ). Two pathways by which $\mathrm{Fe}^{0}$ may reduce nitrate to nitrogen gas or ammonium are as follows:

$5 \mathrm{Fe}^{0}+2 \mathrm{NO}_{3}^{-}+12 \mathrm{H}^{+} \leftrightarrow 5 \mathrm{Fe}^{2+}+\mathrm{N}_{2}+6 \mathrm{H}_{2} \mathrm{O}$

$4 \mathrm{Fe}^{0}+\mathrm{NO}_{3}^{-}+10 \mathrm{H}^{+} \leftrightarrow 4 \mathrm{Fe}^{2+}+\mathrm{NH}_{4}^{+}+3 \mathrm{H}_{2} \mathrm{O}$.

The total nitrogen mass balance was about $95.7 \%$ in which nitrogen as ammonium accounted for $57.4 \%$ and as nitrate for $30.8 \%$ (Fig. 4). Moreover, a small amount of nitrogen gas (7.5\%) was detected.

Five organic buffers, 2-(N-morpholino)ethanesulfonic acid (MES), 3-(N-morpholino)propanesulfonic acid (MOPS), piperazine-N, N-bis(2-ethanesulfonic acid) (PIPES), N-(2-hydroxyehyl)piperazine- $\mathrm{N}$-(2-ethanesulfonic acid) (HEPES) and $\mathrm{N}$ (tris(hydroxymethyl)methyl-3-aminopropanesulfonic acid (TAPS), were chosen by Alowitz and Scherer (2001) to adequately maintain the initial $\mathrm{pH}$ at a range of 5.5-9.0. Some nitrogen loss unaccounted for in this batch experiment may be attributed to: (1) Nitrite sorbed on the iron surface: Liou et al. (2005) have proposed that nitrite remained sorbed to the high reactivity surface of nano- $\mathrm{Fe}^{0}$ particles until the formation of ammonium or nitrogen was achieved, similar to the sequential dehalogenation of carbon tetrachloride to methane as reported by Matheson and Tratnydk (1994). (2) Ammonium adsorption on iron surface was observed in a batch experiment of $\mathrm{N}$-Nitrodimethylamine reduction in previous study (Gui et al., 2000). At initial stage, the total nitrogen mass balance was $99+\%$ because the ammonium formation was not significant. As the amount of ammonium increased, the nitrate removal decreased and remained steady afterward.

\subsection{Electrochemical properties}

Perng and $\mathrm{Wu}$ (2003) indicated that the overall reaction sequence of contaminant-free water $/ \mathrm{Fe}^{0}$ could be summarized as

$$
\begin{aligned}
\mathrm{H}^{+}+e^{-}+\mathrm{Fe}^{0} \rightarrow & \mathrm{Fe}-\underset{\downarrow}{\mathrm{H}_{(\mathrm{ads})}} \\
& +\mathrm{Fe}-\mathrm{H}_{(\mathrm{ads})} \rightarrow 2 \mathrm{Fe}-\mathrm{H}_{(\mathrm{ads})} \rightarrow \mathrm{H}_{2}+\mathrm{Fe}^{2+}+2 e^{-} .
\end{aligned}
$$

Here, the adsorbed hydrogen atoms $\left(\mathrm{H}_{\mathrm{ads}}\right)$, serving as the reducing agent, are formed via the reduction of protons from water at the iron surface (Cheng et al., 1997a,b; Lin et al., 2004). When nitrate was added to the solution, nitrate may have been adsorbed onto the iron surface, and rapidly reduced to ammonia or nitrogen by neighboring $\mathrm{H}_{\text {ads }}$, as shown in Eqs. (4) and (5). The hydrogen concentration on the iron surface, $\left[\mathrm{Fe}-\mathrm{H}_{(\mathrm{ads})}\right]$, plays an important role in the nitrate reduction reaction by $\mathrm{Fe}^{\mathrm{O}}$. The calculation of $\left[\mathrm{Fe}-\mathrm{H}_{(\mathrm{ads})}\right]$ can be expressed by (Perng and $\mathrm{Wu}, 2003$ ):

$\left[\mathrm{Fe}-\mathrm{H}_{(\mathrm{ads})}\right]=\mathrm{Ci}_{0}^{1 / 2}$,

where $i_{0}$ is exchange current density $\left(\mathrm{Acm}^{-2}\right)$ and $C$ is constant. The relative magnitude of $i_{0}$ gives a measure of reaction kinetics. The Tafel profiles of $\log \left|i_{0}\right|$ vs. the applied potentials for $\mathrm{Fe}_{1 \mathrm{M}}^{0}, \mathrm{Fe}_{0.1 \mathrm{M}}^{0}$, and $\mathrm{Fe}_{0.01 \mathrm{M}}^{0}$ are shown in Fig. 5. The $i_{0}$ may be found at the intersection of the extrapolated linear regions of the Tafel curve (Bard and Faulkner, 1980). The $i_{0}$ values are shown in Table $2\left(1.40,3.30\right.$ and $15.8 \times 10^{-7} \mathrm{~A} \mathrm{~cm}^{-2}$ for $\mathrm{Fe}_{1 \mathrm{M}}^{0}, \mathrm{Fe}_{0.1 \mathrm{M}}^{0}$ and $\mathrm{Fe}_{0.01 \mathrm{M}}^{0}$, respectively). The larger $i_{0}$ demonstrates that $\mathrm{Fe}_{0.01 \mathrm{M}}^{0}$ is more reactive in the nitrate solution than both $\mathrm{Fe}_{0.1 \mathrm{M}}^{0}$ and $\mathrm{Fe}_{1 \mathrm{M}}^{0}$, and is consistent with the increase of the denitrification rate exhibited by $\mathrm{Fe}_{0.01 \mathrm{M}}^{0}$. The ratio of $\left[\mathrm{Fe}-\mathrm{H}_{(\mathrm{ads})}\right]_{0.01 \mathrm{M}}:\left[\mathrm{Fe}-\mathrm{H}_{(\mathrm{ads})}\right]_{0.1 \mathrm{M}}:\left[\mathrm{Fe}-\mathrm{H}_{(\mathrm{ads})}\right]_{1.0 \mathrm{M}}$ is approximately 3.35:1.53:1. Besides, the $\left[k_{\mathrm{SA}}\right]_{0.01 \mathrm{M}}:\left[k_{\mathrm{SA}}\right]_{0.1 \mathrm{M}}:\left[k_{\mathrm{SA}}\right]_{1.0 \mathrm{M}}$ is 2.44:1.44:1. These trends indicate that the increase of $i_{0}$ with the rise in $\mathrm{H}_{\text {ads }}$ production led to the rise in chemical

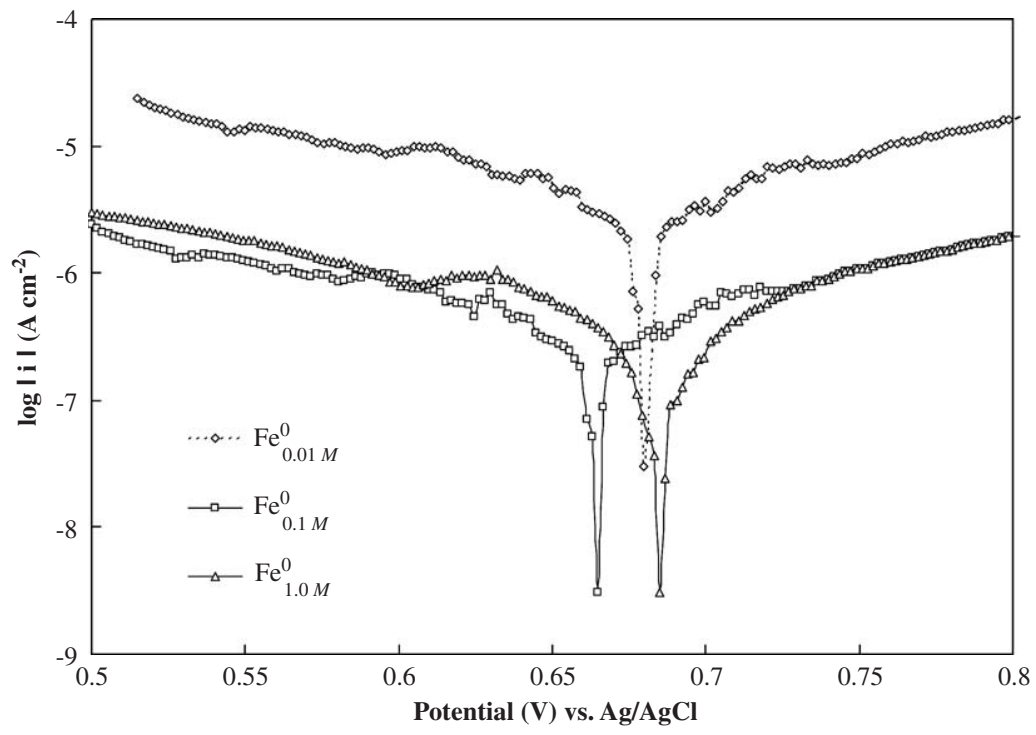

Fig. 5 - Tafel profiles for $\mathrm{Fe}_{1 \mathrm{M}}^{0}, \mathrm{Fe}_{0.1 \mathrm{M}}^{0}$ and $\mathrm{Fe}_{0.01 \mathrm{M}}^{0}$ at Ar-purged buffered $40 \mathrm{mg}-\mathrm{NL}^{-1}$ of nitrate solutions. 
Table 2 - Exchange current density $\left(\mathrm{i}_{\mathrm{o}}\right)$ and $\left[\mathrm{Fe}-\mathrm{H}_{(\mathrm{ads})}\right]_{j \mathrm{M}}$ ratio of $\mathrm{Fe}_{0.01 \mathrm{M}}^{0}, \mathrm{Fe}_{0.1 \mathrm{M}}^{0}$ and $\mathrm{Fe}_{1 \mathrm{M}}^{0}$

\begin{tabular}{|c|c|c|c|}
\hline \multirow[t]{2}{*}{ Reductants } & \multirow[t]{2}{*}{$i_{0}\left(10^{-7} \mathrm{~A} \mathrm{~cm}^{-2}\right)$} & \multirow[t]{2}{*}{$i_{0}^{1 / 2}\left(10^{-4} A^{1 / 2} \mathrm{~cm}\right)$} & {$\left[\mathrm{Fe}-\mathrm{H}_{\text {(ads) }}\right]_{j \mathrm{M}}$ ratio } \\
\hline & & & {$\left[\mathrm{Fe}-\mathrm{H}_{\text {(ads) }}\right]_{1.0 \mathrm{M}}$} \\
\hline $\mathrm{Fe}_{1 \mathrm{M}}^{0}$ & 1.40 & 3.74 & 1 \\
\hline $\mathrm{Fe}_{0.1 \mathrm{M}}^{0}$ & 3.30 & 5.74 & 1.53 \\
\hline $\mathrm{Fe}_{0.01 \mathrm{M}}^{0}$ & 15.8 & 12.6 & 3.35 \\
\hline
\end{tabular}

reactivity in each reactive site on the iron surface. This fact confirms that decreasing the precursor concentration of nanoscale $\mathrm{Fe}^{0}$ increased the chemical reactivity of the particle.

\section{Conclusions}

The results of this study indicate that the precursor concentration is a critical parameter, which controls the nanoscale $\mathrm{Fe}^{\mathrm{O}}$ particle production. The synthesized nanoscale $\mathrm{Fe}^{\mathrm{O}}$ particles were employed for the denitrification of unbufferd $40 \mathrm{mg}^{-\mathrm{N} \mathrm{L}^{-1}}$ nitrate solution at initial neutral $\mathrm{pH}$. The results obtained in this study have demonstrated the following:

(1) The majority of nanoscale particles of $\mathrm{Fe}_{1 \mathrm{M}}^{0}$ and $\mathrm{Fe}_{0.1 \mathrm{M}}^{0}$ are in the size range of $20-60 \mathrm{~nm}$ and $20-70 \mathrm{~nm}$, and the specific surface are 16.16 and $17.50 \mathrm{~m}^{2} \mathrm{~g}^{-1}$, respectively. However, an absolutely reduced size $(9-10 \mathrm{~nm})$ and greatest specific surface area $\left(56.67 \mathrm{~m}^{2} \mathrm{~g}^{-1}\right)$ results with production under $0.01 \mathrm{M}$ condition.

(2) The nanoscale $\mathrm{Fe}^{0}$ particles could effectively remove nitrate without acidification. The first-order degradation rate constants $\left(k_{\text {obs }}\right)$ follow the trend $\mathrm{Fe}_{0.01 \mathrm{M}}^{0}>\mathrm{Fe}_{0.1 \mathrm{M}}^{0}>$ $\mathrm{Fe}_{1 \mathrm{M}}^{0}$.

(3) The reactivity of $\mathrm{Fe}_{0.01 \mathrm{M}}^{0}$ particles surface was higher than that of $\mathrm{Fe}_{1 \mathrm{M}}^{0}$ and $\mathrm{Fe}_{0.1 \mathrm{M}}^{0}$ as indicated by a larger $k_{\mathrm{SA}}$ for $\mathrm{Fe}_{0.01 \mathrm{M}}^{0}$. A rising reactivity 1.69-2.44 times that of $\mathrm{Fe}_{0.01 \mathrm{M}}^{0}$ particles on a mass basis.

(4) The largest $i_{0}$ demonstrated the rise in $\mathrm{H}_{\text {ads }}$ production, and led to highest chemical reactivity in each reactive site on the iron surface.

R E F E R E N C E S

Alowitz, M.J., Scherer, M.M., 2001. Kinetic of nitrate, nitrite and $\mathrm{Cr}(\mathrm{VI})$ reduction by iron metal. Environ. Sci. Technol. 36, 299-306.

Bard, A.J., Faulkner, L.R., 1980. Electrochemical Methods. Wiley, New York.

Cheng, I.F., Fernando, Q., Korte, N., 1997. Electrochemical dechlorination of 4-chlorophenol to phenol. Environ. Sci. Technol. 31, 1074-1078.

Cheng, I.F., Muftikian, R., Fernando, Q., Korte, N., 1997. Reduction of nitrate to ammonia by zero-valent iron. Chemosphere 35 , 2689-2695.
Choe, S., Chang, Y.Y., Hwang, K.Y., Khim, J., 2000. Kinetic of reductive denitrification by nanoscale zero-valent iron. Chemosphere 41, 1307-1311.

Choe, S., Liljestrand, H.M., Khim, J., 2004. Nitrate reduction by zero-valent iron under different $\mathrm{pH}$ regimes. Appl. Geochem. 19, 335-342.

Ellott, D.W., Zhang, W.X., 2001. Field assessment of nanoscale bimetallic particles for groundwater treatment. Environ. Sci. Technol. 35, 4922-4926.

Gui, L., Gillham, R.W., Odziemkowski, M.S., 2000. Reduction of NNitrosodimethylamine with granular iron and nickel-enhanced iron. 1. Pathways and kinetics. Environ. Sci. Technol. 34, 3489-3494.

Huang, C.P., Wang, H.W., Chiu, P.C., 1998. Nitrate reduction by metallic iron. Water Res. 32, 2257-2264.

Ichinose, N., Ozaki, Y., Kashu, S., 1992. Superfine Particle Technology. Springer, London.

Kielemoes, J., Boever, P.D., Verstraete, W., 2000. Influence of denitrification on the corrosion of iron and stainless steel powder. Environ. Sci. Technol. 34, 663-671.

Liao, C.H., Kang, S.F., Hsu, Y.W., 2003. Characteristics of reductive removal of nitrate by suspended zero-valent iron powder. J. Chinese Inst. Environ. Eng. 13, 251-261.

Lin, C.J., Lo, S.L., Liou, Y.H., 2004. Dechlorination of trichloroethylene in aqueous solution by noble metal-modified iron. J. Hazard. Mater. 116, 219-228.

Liou, Y.H., Lo, S.L., Lin, C.J., Kuan, W.H., Weng, S.C., 2005. Treatment of an unbuffered nitrate solution using Fe and $\mathrm{Cu} / \mathrm{Fe}$ nanoparticles. J. Hazard. Mater. 127, 102-110.

Matheson, L.J., Tratnydk, P.G., 1994. Reductive dehalogenation of chlorinated methanes by iron metal. Environ. Sci. Technol. 28, 2045-2053.

Perng, T.P., Wu, J.K., 2003. A brief review note on mechanisms of hydrogen entry into metals. Mater. Lett. 57, 3437-3438.

Ponder, S.M., Darab, J.G., Mallouk, T.E., 2000. Remediation of Cr(VI) and $\mathrm{Pb}$ (II) aqueous solutions using supported nanoscale zerovalent iron. Environ. Sci. Technol. 34, 2564-2569.

Schlicker, O., Ebert, M., Firth, M., Weidner, M., Wust, W., Dahmke, A., 2003. Degradation of TCE with iron: the role of competing chromate and nitrate reduction. Ground Water 38 , 403-409.

Schrick, B., Blough, J.L., Jones, A.D., Mallouk, T.E., 2002. Hydrodechlorination of trichloroethylene to hydrocarbons using bimetallic nickel-iron nanoparticles. Chem. Mater. 14, 5140-5147.

Siantar, D.P., Schreier, C.G., Chou, C.S., Reinhard, M., 1996 Treatment of 1,2-dibromo-3-chloropropane and nitrate-contaminated water with zero-valent iron or hydrogen/palladium catalysis. Water Res. 30, 2315-2322.

Söhnel, O., Garside, J., 1992. Precipitation: Basic Principles and Industrial Applications. Butterworth-Heinemann Ltd., London. 
Su, C., Puls, R.W., 2004. Nitrate reduction by zerovalent iron: effect of formate, oxalate, citrate, chloride, sulfate, borate, and phosphate. Environ. Sci. Technol. 38, 2715-2720.

Vivier, V., Cachet-Vivier, C., Wu, B.L., Cha, C.S., Nedelec, J.Y., Yu, L.T., 1999. Cavity microelectrode for studying powder materials at a high potential scan rate. Electrochem. Solid-State Lett. 2, 385-387.
Wang, C.B., Zhang, W.X., 1997. Synthesizing nanoscale iron particles for rapid and complete dechlorination of TCE and PCBs. Environ. Sci. Technol. 31, 2154-2156.

Westerhoff, P., James, J., 2003. Nitrate removal in zero-valent iron packed columns. Water Res. 37, 1818-1830.

Zhang, W.X., Wang, C.B., Lien, H.L., 1998. Treatment of chlorinated organic contaminants with nanoscale bimetallic particles. Catal. Today 40, 387-395. 